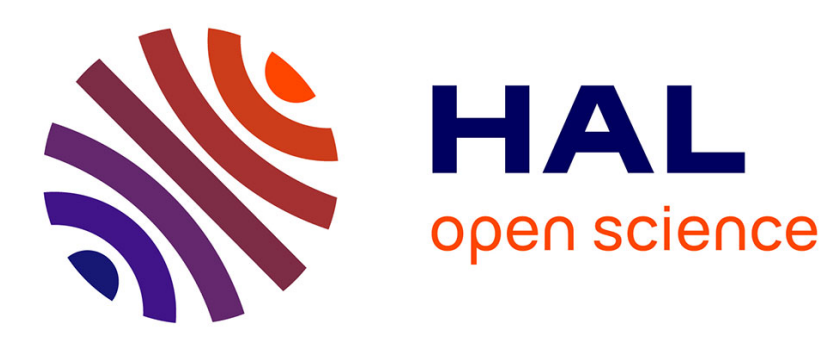

\title{
The Role of International Actors in Post-Communist Countries: Coercion or Persuasion? The Transfer of Hospital Design Standards by International Organizations and Private Firms
}

\author{
Rodica Plugaru
}

\section{To cite this version:}

Rodica Plugaru. The Role of International Actors in Post-Communist Countries: Coercion or Persuasion? The Transfer of Hospital Design Standards by International Organizations and Private Firms - American Political Science Association Annual Meeting, Aug 2013, Chicago, IL, United States. 10.2139/ssrn.2335406 . hal-01342315

\section{HAL Id: hal-01342315 \\ https://hal.science/hal-01342315}

Submitted on 5 Jul 2016

HAL is a multi-disciplinary open access archive for the deposit and dissemination of scientific research documents, whether they are published or not. The documents may come from teaching and research institutions in France or abroad, or from public or private research centers.
L'archive ouverte pluridisciplinaire HAL, est destinée au dépôt et à la diffusion de documents scientifiques de niveau recherche, publiés ou non, émanant des établissements d'enseignement et de recherche français ou étrangers, des laboratoires publics ou privés. 


\author{
Rodica PLUGARU \\ PhD Institute of political studies, PACTE, Grenoble, France \\ rodica.plugaru@iepg.fr
}

\title{
The Role of International Actors in Post-Communist Countries: Coercion or Persuasion? The Transfer of Hospital Design Standards by International Organizations and Private Firms ${ }^{1}$
}

\begin{abstract}
:
This paper explores the role of international actors in post-communist transformation. By taking the case of hospital design standards, it explains how the national actors choose to leave aside the national regulations and to adopt foreign technical standards. The paper takes the case of technical standards employed for the modernization of healthcare facilities in Ukraine and Moldova. An in-depth comparative case study of two projects revealed that national architects of these post-soviet countries use foreign standards. While the change of standards is a similar outcome in both cases, the international actors involved are different. My findings suggest that while both international organizations and private actors diffuse foreign technical standards in post-soviet countries, the processes through which they realize it differs. Whereas international organizations dispose of coercive means to impose foreign solutions, private actors need to negotiate and to convince for their adoption. Drawing on recent debates on policy diffusion and transfer (Dolowitz and Marsh 2012; 2000, Simmons and al. 2008, Stone 2010, 2012), the results shed light on "carriers" of institutional arrangements among different political systems.
\end{abstract}

Key words: transfer, standards, international actors, post-soviet states

\footnotetext{
${ }^{1}$ Paper presented at the international conference in political science APSA, Chicago, United States, 2013.
} 


\section{Introduction}

This paper explores the role of international actors in post-soviet countries modernization, by taking the case of hospital design in Ukraine and Moldova between 1991 and 2011 ${ }^{2}$. By late 2000, both Ukraine and Moldova started to modernize the inherited hospital buildings, while aiming to adopt international standards ${ }^{3}$. We question the role of foreign actors, such as private firms and international organizations that participated at hospital building reconstruction in these post-soviet countries.

The post-soviet states, such as Ukraine and Moldova, represent a stimulating research object for the study of policy transfer. Given the fact that these states did not join the European Union yet, their institutional developments following the Soviet Union's collapse could be influenced by multiple and various foreign actors ${ }^{4}$. Taking a concrete case of public policy such as the modernization of healthcare facilities, we analyze the roles of international organizations and of private actors in transferring the foreign experience of hospital design. We focus on the strategies developed by the foreign actors to introduce the international experience in these post-soviet states, as well as on their interactions with the national actors and institutions.

Our main hypothesis is that international organizations have more pressure means than the private firms to introduce the foreign experience, thus using of more coercive transfer mechanisms.

In order to study the role of international actors in post-soviet states, we draw on the literature on policy transfer. We adopt the definition of transfer of David P. Dolowitz and David Marsh: "the process by which knowledge about policies, administrative arrangements, institutions and ideas in one political system (past or present) is used in the development of policies, administrative arrangements, institutions and ideas in another political system"5. Additionally, we use the terms of coercion and learning, based on the diffusion mechanisms developed by

\footnotetext{
${ }^{2}$ The paper presents one of the results of our $\mathrm{PhD}$ study on the "International transfers and institutional changes in post-soviet states: the case of building hospital standards evolution in Ukraine and in Moldova (1991-2011)" prepared at the Institute of Political Studies of Grenoble, France.

${ }^{3}$ We do not detail in this article the content of the international standards, but notice that it concerns the recommendations of foreign actors of what is the «appropriate » practice, procedure and way of doing for an activity domain. The standards are to be differentiated of social norms (relative to the human behavior) or of regulations (formal documents with obligatory character), for more details refer to Brunsson, Nils et al., dir. $A$ world of standards. New York: Oxford University Press Inc., 2000).

${ }^{4}$ In a main article on Europeanization and institutional transfer, Sabine Saurugger and Yves Surel point to the fact that what usually is analyzed under the conceptual framework of Europeanization (member states or even potential ones) should seriously take into account the multiple possible external influences: Saurugger, Sabine et Yves Surel, «L'élargissement de l'Union européenne : un processus de transfert institutionnel ?», Introduction 13, no. 2 (2006), 177-8.

${ }^{5}$ Dolowitz, David P. et David Marsh, «Learning from Abroad: The Role of Policy Transfer in Contemporary Policy-Making», Governance 13, no. 1 (2000), 5-23., p.5.
} 
Beth Simmons and $\mathrm{al}^{6}$. If coercion it the mechanism through which a more powerful external actor influence domestic changes, learning takes place in a less asymmetrical relation. According to Katharina Füglister, learning can be defined as the process through which national actors use the foreign countries experience ${ }^{7}$. These conceptual markers will be used to characterize the degree of international actors' influence in Ukraine and Moldova.

The actors participating at transfer process can be very various ${ }^{8}$ : states, international organizations, non-governmental organizations, civil servants, consultants, etc. In line with the latest work on non-state actors of Diane Stone ${ }^{9}$, this paper seeks to detail the role of international organizations, such as the World Bank, as well as of private firms, such as architecture and engineering design practices. If usually the action of international organizations is analyzed as coercive, through the economic and political conditionality, we seek to detail its role by focusing on the technical assistance provided to post-soviet countries $^{10}$. In Moldova, the World Bank not only granted credit resources for the modernization of healthcare facilities, but also supervised its implementation and provided technical assistance to national actors. We question how the participation of World Bank consultants to the healthcare development in Moldova influenced the adoption of international standards of design. In Ukraine, we detail the role of economic actors, such as private firms, in transferring the hospital design standards of their countries. If the transfer literature omits the influence of this type of actors, we argue that their role should be more systematically analyzed. As shows our Ukrainian case, the private firms can be "carriers" of international standards: while realizing different economic missions, they develop strategies of "selling" their foreign experience to post-soviet states.

This paper is structured in three sections. First, we introduce the analyzed projects. In Ukraine, the wife of former President Viktor Yoshchenko and the Foundation Ukraine 3000 realized the main hospital modernization since the Soviet Union's collapse. This project gathered numerous national and international actors. We focus on the foreign private firms that were appointed to the design of the Ukrainian hospital. In Moldova, we present the case of the modernization of primary healthcare facilities - the Health Centers. This project was chosen because it is the only modernization of public medical building realized following the

\footnotetext{
${ }^{6}$ We adopt the diffusion mechanisms in order to complete the conceptual framework on transfer, which does not detail the latter so successfully : Simmons, Beth A. et al., The Global Diffusion of Markets and Democracy (New York: Cambridge University Press, 2008).

${ }^{7}$ Füglister, Katharina, «Where does learning take place? The role of intergovernmental cooperation in policy diffusion», European Journal of Political Research 51, no. 3 (2012), 316-49., p. 319.

${ }^{8}$ See for example the state of the art of the transfer literature and particularly the role of various actors in Delpeuch, Thierry, «L'analyse des transferts internationaux de politiques publiques : un état de l'art», Questions de recherche, no. 27 (2008).

${ }^{99}$ Diane Stone particularly focused on the role of foundations, non-governmental organizations, think-tanks in the process of international transfers: Stone, Diane, «Non-Governmental Policy Transfer: The Strategies of Independent Policy Institutes», Governance 13, no. 1 (2000), 45-70, Stone, Diane, «Private philanthropy or policy transfer? The transnational norms of the Open Society Institute», Policy \& Politics 38, no. 2 (2010), 26987.

${ }^{1010}$ On the different types of influence of international organizations, see Nay, Oliver, «How Do Policy Ideas Spread among International Administrations? Policy Entrepreneurs and Bureaucratic Influence in the UN Response to AIDS», Journal of Public Policy 32, no. 1 (2012), 53-76.
} 
independence and because of the participation of the World Bank. The second section questions the reasons of international actors to introduce their experience in post-soviet states, while pointing to the obstacle to this process. Given the fact that both Ukraine and Moldova experience more than fifty years of soviet background, we question the presence of similar institutional arrangements, such as the building regulations, to the international transfer. Finally, the third section introduces the mechanisms through which the World Bank in Moldova and the private firms in Ukraine convinced the national actors to adopt foreign design standards.

In comparing two projects of healthcare modernization, we used data from our PhD research. In Ukraine, we observed the "making-of" of the Kiev hospital within the French private practice Groupe-6 during a three-year doctoral collaboration. In Moldova, we realized a two months internship at the Ministry of Health and collected data on several modernization projects. Additionally, we realized 93 interviews with architects, engineers, consultants, civil servants and officials from Ukraine, Moldova, France and the United Kingdom, some of which will be mentioned. 


\section{I ) How do international actors participate to hospital projects in post- soviet states? The case of an international organization in Moldova and a private firm in Ukraine}

The first decade following the independence of Ukraine and Moldova saw no significant investment in the hospital sector, as other points of the health care system (the primary sector and the health insurance) were considered more essential ${ }^{11}$. The only hospital concern was linked to the reduction of healthcare facilities oversupply. During the Soviet Union, both republics had a large number of hospital beds, which exceeded the local population needs. Following the independence, both reduced the number of hospitals ${ }^{12}$. Nevertheless, despite the infrastructure reduction, hospital buildings remained those inherited of the Soviet Union. No resources were invested in remodeling the health care buildings neither of primary sector (medical centers), nor of secondary or tertiary sector (hospitals).

By the end of 2000, both Ukraine and Moldova started modest investments in modernizing the inherited infrastructures. The dilapidated nature of inherited health care facilities started to become a problem of public interest. Despite the fact that the number of hospitals was reduced following the independence, the ones in place functioned within extremely poor conditions. The same applied to primary health care facilities, such as polyclinics. A World Health Organization report on Ukraine mentions for example that "Ten per cent of the physician respondents reported having no or insufficient access to X-ray facilities. Around half of the patients surveyed were dissatisfied with the premises and a large majority $(74 \%)$ indicated that their policlinic or ambulatory had insufficient equipment"13. Besides the lack of medical equipment, there was also a lack of medical technologies which strengthened the problem of realizing complex surgical interventions. The ministries of health of both countries had to reorient patients for more complex treatment in healthcare facilities abroad ${ }^{14}$. There was a lack of modern medical equipment and technologies, as well as appropriate infrastructures for it, at the national level. It is in this context, that Ukraine and Moldova launched, by the end of 2000, several modernizations of old health infrastructures. In Ukraine, it was part of a Presidential initiative, under the direction of Viktor Youshchenko's wife association. In Moldova, it followed a national program of healthcare system reform, sustained by international organizations and especially, by the World Bank. Political leaders of both post-soviet republics declared the willingness to integrate international standards in the new hospital buildings.

\footnotetext{
${ }^{11}$ This can be explained by the fact that during the Soviet Union, the primary sector was slightly developed, so it got the first attention on the public agenda. See for example the very well documented reports of the European Observatory of the World Health Organization (Euro WHO) for Ukraine and Moldova: Lekhan, Valery et al., Ukraine: Health system review, ed. European Observatory on Health Systems and Policies. Copenhagen: Euro WHO, 2010).; Atun, Rifat et al., Moldova: health system review (dans Health Systems in Transition, ed. The European Observatory on Health Systems and Policies: Euro WHO, 2008).

${ }^{12}$ As mentions a recent Euro WHO report on Moldova, there is still an oversupply of hospital beds in the country and especially in the capital Chisinau, Turcanu, Ghenadie et al., Republic of Moldova: Health system review, ed. the European Observatory on Health Systems and Policies. Copenhagen: Euro WHO, 2012), p. XVIII.

${ }^{13}$ Lekhan, Valeria et al., Health care systems in transition: Ukraine (Copenhagen: WHO Regional Office for Europe on behalf of the European Observatory on Health Systems and Policies, 2004)., p. 18.

${ }^{14}$ Observation collected during our research internship in Ukraine and Moldova, March-May 2010.
} 


\section{A) The Children Hospital of the Future, in Kiev, Ukraine}

In 2006, the Foundation Ukraine 3000, run by President's wife Kateryna Youshchenko ${ }^{15}$, started a national tour of healthcare facilities. The first lady reports of deplorable conditions of hospitals, especially for children, gave birth to the idea of the Hospital of the Future - a new modern facility, created upon the international standards, providing the latest medical equipment and technologies. The idea of creating the new hospital facility met the national health care priorities for treating the cancer disease of mother and children of Ukraine, for which the level was very high. The Foundation Ukraine 3000 presented the project to the President of Ukraine and to the Ministry of Health. The national leaders discussed the Foundation's project together with the possibilities of restructuring one of the existent hospitals in Kiev. The construction of a new hospital - the Children Hospital of the Future was retained. The political will was to create a completely new medical institution, different of inherited hospital buildings and modeling the best hospital practices of Western countries (in terms of medical equipment and technologies, as well as making of complex surgical interventions). On May 2006, the Ukrainian President Viktor Youschenko edited a Decree launching the project of the Hospital of the Future of Kiev. The Foundation Ukraine 3000 was missioned to realize the architectural design stage of the project, while the Ukrainian state had to realize the following stage - its construction.

The project of the Children Hospital of the Future, in Kiev, engaged a large amount of national resources. The Foundation Ukraine 3000 launched a national fund collection among Ukrainian citizens, businessmen and members of Diaspora. As their representatives used to say, it was the first time that such a charitable operation was realized in Ukraine and that it benefited of the support of the whole country, including political members of different sides of the fence. In parallel to the fund collect, the Foundation representatives visited hospital facilities abroad. The aim of these actions was double: on one hand, the Foundation collected funds from the Diaspora and on the other hand, gathered information on the hospital developments of Western countries (visits were made in the United States, Canada, United Kingdom, Germany etc.). During these foreign experiences, the Foundation representatives who were to be invested in realizing the Children Hospital of the Future, became familiar with the hospital functioning, the hospital design as well as the medical procedures of western medical facilities. There was the clear idea of realizing in Ukraine a hospital institution on the image of the most advanced hospitals of the developed countries.

Following the fund collect, the Foundation Ukraine 3000 launched an international design competition in order to attract foreign architects for the realization of the Children Hospital of the Future. The Ukrainian leaders considered that national architects would not know to design a hospital the way could the foreign ones. Even if they insisted on the fact that it was an open competition and that Ukrainian firms could participate, they highlighted the fact that they did not want a new hospital at the image of the inherited buildings. The fact that the Foundation made a list of foreign firms specialized in hospital design and contacted them

\footnotetext{
15 The Foundation Ukraine 3000 was previously run by the President Viktor Youshchentko himself. While the latter developed more cultural action, in particularly in favor of recognizing the Ukrainian famine "golodomor", Kateryna Youshchenko put emphasis on development of the health care sector.
} 
directly to invite in the competition is another argument to the willingness to attract foreign experience of hospital design en Ukraine. A final stage between three firms (English, Italian and Ukrainian) declared, in June 2006, the Anglo-French consortium "bdpgroupe6" the future architects of the Hospital of the Future. The foreign architects were chosen by a jury of national members (Foundation members, Ukrainian architects, entrepreneurs...) and international representatives (architects and doctors from abroad). Bdpgroupe6 was chosen on the basis of a project design sketch, which included a preview image of the future hospital. This point started a three-year collaboration started between the national actors - Foundation Ukraine 3000 - and the international actors - bdpgroupe6 - for the hospital design of the Children Hospital of the Future, in Kiev.

\section{B) The primary health care centers in Moldova}

The modernization of Centers of primary healthcare ${ }^{16}$ in Moldova was part of a broader Strategy of Development of the Primary Assistance, put in place by the Ministry of Health. In 2007, the ministry elaborated a feasibility study concerning the current estate of the primary sector $^{17}$. The study made the inventory of all existing medical institutions, the technical conditions of the buildings, the equipments and the medical personnel. It was revealed that the existing centers did not respond to optimal conditions for functioning as medical institutions: $80 \%$ of them did not have canalization system and water (only from the well); $49 \%$ were built before 1980; $80 \%$ did not dispose of medical equipment and furniture ${ }^{18}$. Following these conclusions, the Ministry of Health promoted several proposals to the Government of Moldova, especially concerning the attractiveness of medical staff in the rural areas. In the same time, international organizations joined the initiated national actions in the primary sector. The financial aid was provided by several international organizations. There was the World Bank Program "Health care Services and Social Assistance" (about 5 million dollars to the medical assistance in rural areas), but also the financial support of the European Union through the TACIS program "The support of healthcare reform. The consolidation of primary medical assistance in Moldova" (for which 4.5 million dollars were attributed). Among these different foreign actors, we chose to analyze the involvement of the World Bank. The latter's support concerned more specifically the modernization of the buildings, while that of the European Union was related to the purchase of medical equipment. Thus, the concern for the building remodeling allows the comparison with the construction of a new hospital building in Ukraine.

\footnotetext{
16 The Health Centers (or the Centers of primary healthcare) are, in Republic of Moldova, medical institutions in rural areas. These are small buildings, with laboratory equipment, transportation and department of family doctor. Ministry of Health of Republic of Moldova. 2003. Order of the Ministry of Health regarding the institution of the health structure of region/municipality/ Ordin al Ministerului sanatatii cu privire la instituirea structurii sistemului sănătăţii raionale/municipale. 190.

${ }^{17}$ This document was prepared with the support of the Japanese Government aid grant, Ministry of Health of Republic of Moldova, Report of activity of Miistry of Health for the year 2007/Raport de activitate a Ministerului Sanatatii pentru anul 2007. Chisinau, Moldova, 2008)., p.26.

${ }^{18}$ Ibid.
} 
The World Bank support for the primary sector in Moldova was part of a more extensive Program of Assistance to the Moldavian Government. The latter obtained a World Bank credit of 17 million dollars for the project "Health care and social assistance services" (HSAS) in June 2007. The funds aimed to sustain the Government Program of increasing the health care services and social assistance to the Moldavian population. This national project was implemented during 2007 and 2011 by two central administrations: the Ministry of Health and the Ministry of the social protection and of the family. Within this very large program of assistance, a piece was dedicated to the primary health sector in order to strengthen the actions started by the Ministry of Health in this field ${ }^{19}$.

To get into details, the Ministry of Health received a credit of about five million dollars from the World Bank, under the component " 1.3 - The development of primary medical assistance" ${ }^{, 20}$. Although one of the program components concerned the hospital sector and the modernization of a main hospital of the country ${ }^{21}$, we chose to analyze an example of modernization of primary health care facility because this sector was more developed. As reports the General Accounting Office of Moldova, by 2010, the component of primary medical assistance was realized up to $70 \%$ of the sum credited by the World Bank, while the hospital component was scarcely attaining $20 \%$ of the used resources ${ }^{22}$. In this context, the modernization of primary facilities is more advanced in Moldova than the modernization of hospitals, which was at its beginnings. The observation of a concrete and finalized project of medical building modernization allows questioning more precisely the role of the World Bank in the introduction of international standards.

The project of the modernization of primary care facilities in rural areas concerned the reconstruction of some of existing ones and the construction of new Centers where necessary. This involved not only the improvement of building conditions, but also the provision of advanced medical equipment and technologies. We stress here the fact that according to the new medical equipment, the healthcare centers were also supposed to change their architectural layouts. Because of the changing dimensions of new medical equipments, the areas and the disposal of modernized centers were supposed to be modified (this point will be developed later on). Therefore, the modernization of primary care buildings was linked to the provision of new and more advanced equipments (with new technical characteristics, sizes etc.).

\footnotetext{
19 The HSAS project contained four main axes: 1) health care services; 2) improvement of the system of protection and social assistance; 3 ) management of the project; 4) healthcare and nutrition status protection. The first point - the "health care services" - was implemented by the Ministry of Health and concerned various aspects (from the development of the medical assistance to evaluating hospital capacity and their modernization). ${ }^{20}$ General Accounting Office of the Republic of Moldova, Audit Report of the project "Healthcare and Social Assistance Services" for the period 2007-2010/ Raportul auditului operațional al Proiectului „Servicii de Sănătate şi Asistență Socială” pentru perioada iunie 2007- 2010. Chisinau, Moldova: Curtea de conturi a Republicii Moldova, 2011).

${ }^{21}$ The Clinical Republican Hospital was part of a project of building restructuring within the World Bank program, but it is not taken for our present analysis, because it still ongoing while we are writing the article. Although the comparison with Ukrainian case would have been more precise (two hospital projects), there is not for the moment any other project of modernization of medical facility in Moldova realized with the World Bank support, apart the Centers of primary assistance in rural areas.

${ }^{22}$ General Accounting Office of the Republic of Moldova, op. cit., p. 5.
} 
It can be concluded that at the difference of the Ukrainian project of the Children Hospital of the Future, the re/construction of the Centers of primary healthcare in Moldova was launched with the financial support of the World Bank. Besides, there was no international selected firm for this project. Only local companies were appointed for remodeling the existing facilities or constructing new ones ${ }^{23}$. Another difference between the cases concerns the expressed willingness to adopt international standards of building design. The Moldavian Ministry of Health did not express the introduction of international standards while re/building the primary Centers ${ }^{24}$, compared to Ukrainian Foundation who insisted on the creation of a hospital based on the design experience of advanced countries. In addition, Ukrainian leaders made an international tour in order to inspire themselves of the most advanced developments in hospital design, but also medical equipment and technologies that were used by western hospitals.

Regarding a process of transfer of hospital design standards, it can be observed that in the Ukrainian project, national actors have started evaluating hospitals abroad. In the same time, they did not put in place a concrete working document of the specific western hospital characteristics to be adopted in Ukraine. At this early stage of the project, the visits abroad can be considered as a beginning of learning. National actors want to see in their own country a hospital at the image of those of western countries because they consider them to be efficient, because they see how they function, the advanced equipments and technologies they have, as well as the health care services they provide. From this point of view, the process of importing the foreign experience can be characterized of learning, where national actors inform themselves and evaluate the foreign solution before importing them. It can be differentiated of emulation, where the national actors would want to have a western hospital without knowing its characteristics and only knowing that this is "the trend" in current hospital development. It also can be observed that international actors were not present neither in Ukraine, nor in Moldova, during these early stages. The World Bank in Moldova credited resources for the project of $\mathrm{CPH}$, but this went along with the Government previous initiatives of developing the primary sector. This is even more visible in Ukraine, where international firms integrated the hospital project only by the moment of the design competition. Consequently, the launch of healthcare modernization facilities in Ukraine and in Moldova was realized at the initiative of national actors. If in Ukraine, political leaders engaged in a process of learning in order to adopt hospital design developments of Western countries, in Moldova, there was apparently no particular will of observing the primary healthcare facilities of other countries. The presence, in both cases, of international actors

\footnotetext{
${ }^{23}$ The absence of international design firms for the Moldavian project can be explained by the fact that the financial resources were less important (around 800000 dollars for a Center reconstruction in Moldova, 120 million dollars construction cost of the Ukrainian hospital). Second, while in Ukraine the operation concerned the construction of a new hospital, the modernization of Centers in Moldova was essentially reconstruction, which can be less motivating in terms of design for international firms.

${ }^{24}$ It should, however, be mentioned here that the Ministry of Health stated the respect of "international technological standards" for the medical services provided in the Centers of primary assistance. Nevertheless, this point concerned the type of service provided (primary care, different of secondary care provided in hospitals, related with the population reached as well as the competence of medical personnel, all of which were more or less neglected during the Soviet Union) and not the standards of building design, Ministry of Health of Republic of Moldova, op. cit., p. 30.
} 
during the next phases of the project, allows investigating their influence on an eventual transfer of foreign experience.

In sum, we will question the role of international actors in Ukraine and Moldova through the analysis of two different cases: a hospital project construction in Ukraine versus a primary care re/construction project in Moldova. In the same time, both projects concern the modernization of healthcare facilities (primary care in Moldova and tertiary care (hospital) in Ukraine). International actors are present in both projects, although they are different organizations: private firms in Ukraine and international organization in Moldova (Table 1). We will now turn to the way these two different actors engaged in a transfer of design standards in order to details the similar or different characteristics of this process.

Table 1: International and national actors of the two projects ${ }^{25}$

\begin{tabular}{|c|c|c|}
\hline Cases & UKRAINE & MOLDOVA \\
\hline Project & Children Hospital of the future & $\begin{array}{c}\text { Primary care Centers in } \\
\text { rural areas }\end{array}$ \\
\hline $\begin{array}{c}\text { National actors } \\
\text { public investors) }\end{array}$ & Foundation of wife's President & Ministry of Health \\
\hline $\begin{array}{c}\text { International } \\
\text { actors }\end{array}$ & Anglo-French design firm "bdpgroupe6" & World Bank \\
\hline
\end{tabular}

\footnotetext{
${ }^{25}$ The actors named in the table are reduced for the purpose of the article. There are several other national, as well as international actors of these projects, but which were not retained for our present study. Our aim is to focus on these types of actors in order to observe if their different nature (international organization and international design firms) produced different forms of transfer of standards in the health sector modernization of Ukraine and Moldova.
} 


\section{II ) The international actors as "carriers" of foreign hospital design standards}

In this second part of the article, we present how the international actors participated at introducing the foreign experience of designing a healthcare facility. If the Anglo-French consortium bdpgroupe6 was called in Ukraine to design a hospital upon their international experience, no such demand was presented to the World Bank in Moldova. Yet, in both cases, the foreign actors insisted for adopting the international standards of building a facility, while deviating from national regulations of these countries. We explain here the reasons of this position.

\section{A) The international actors face to the national regulations of post-soviet countries}

The mission of international actors in the Ukrainian and Moldavian projects was different. In Ukraine, bdpgroupe6 had to develop the design of the Children Hospital of the Future. In Moldova, the World Bank participated with financial resources and did not realize the re/construction of the primary Centers, for which local companies were appointed. In the same time, because of the credited resources, the international organization had an eye on the proceedings of the project. So the foreign actors intervened in both cases, although within different missions and at different moments.

As previously mentioned, the Foundation Ukraine 3000 selected the Anglo-French consortium bdpgroupe6 for designing the Children Hospital of the Future. The organization clearly expressed the willingness to obtain a hospital design upon the international experience $^{26}$. In the same time, following the competition, the Foundation required the respect of national Ukrainian building regulations by international consultants. This concerned the obtaining of certificates from the national administrative authorities and especially the building permit ${ }^{27}$. The fear of the Ukrainians was to get a foreign piece of hospital design that would not be approved by local authorities and that they would not be able to build in practice. For this, the Foundation asked the foreign architects to introduce a local partner in their team. In addition, it stipulated in the contract the obligation of obtaining the building permit: if bdpgroupe6 did not obtain it, they would not receive one large part of their payment.

If bdpgroupe6 integrated a local company ${ }^{28}$ - the Ukrainian architects from Budova Centre-1 - in its team, it did not accepted so easily to conform to Ukrainian regulations. Before signing the contract with the Foundation, the consortium questioned the impact of Ukrainian regulations on their mission. Given the fact that Ukraine was a post-soviet country, they wanted to know if its national building regulations would not constitute an obstacle for implementing their hospital design experience. First, the foreign architects started to inform

\footnotetext{
${ }^{26}$ This was specified in the mission's document provided to bdpgroupe6, consulted by the author.

${ }^{27}$ In Ukraine, the building permit is delivered by a national commission called "Expertyza" which checks upon the design project conformity with the national Ukrainian regulations before emitting its authorization.

${ }^{28}$ The Anglo-French firm bdpgroupe6 initially composed of several foreign companies: Groupe-6, architecture French company, BDP, British engineering company and EC Harris, British building consultancy company. Later, bdpgroupe6 was joined by Budova Centre-1, Ukrainian architecture company.
} 
about the Ukrainian technical norms. They got the documents of the Ukrainian norms and tried to translate them. This task proved to be very tedious. It rapidly became obvious that studying the Ukrainian regulations will be complicated, because of their very large number, as well as because of their specificity ${ }^{29}$. Second, bdpgroupe6 asked advice from the local architect Budova ${ }^{30}$. The latter explained that respecting the Ukrainian regulations meant to completely reevaluate the foreign design proposal. Budova made clear that the future hospital would not look like the sketch design proposed at the competition, but like an ordinary Ukrainian hospital:

"The Client (the Foundation) wants an European design hospital. In the same time, they want the Ukrainian regulations be applied. This is non-sense. The Ukrainian norms we have are those of the soviet period. If I apply them, I completely change the design of bdpgroupe 6 and that they presented at the international competition. I can do this, but is really a lot of work. The project needs to be redesigned"31.

Following the consultations with local architect and taking also into account the visual differences between hospitals of Ukraine and those of their own countries, the foreign architect estimated that respecting the national building norms of Ukraine did not allow them to maintain their hospital design. Additionally, this would have reduced their architectural mission to the profit of the local architect, who would strongly adapt it to the Ukrainian design characteristics.

The incompatibility of foreign hospital design with the Ukrainian regulations created a conflict between the Foundation Ukraine 3000 and the international consortium bdpgroupe6. The two parts handled negotiations during several months before signing the contract. Thus, even if bdpgroupe6 was selected by July 2007, the contract for the designing the Children Hospital of the Future was only signed by December 2007. Both sides opposed on the subject of Ukrainian building norms respect. The Foundation did not want a project design which would not be accepted in Ukraine and thus put the clause of obtaining the building permit from the authorities as a contractual obligation. In the same time, the Foundation wanted the foreign architects to present a hospital design upon their international experience. Their members insisted on the fact that foreign architects need to design the Kiev hospital on the image of the most advanced medical institutions of their countries (France, United Kingdom...). In response, bdpgroupe 6 explained that implementing their experience while respecting the Ukrainian regulations would be impossible. The foreign firms wanted to obtain the permission of working more freely if putting in practice their experience. Their motivation was linked both to economic reasons (more important fees than the local architect) and

\footnotetext{
${ }^{29}$ The Ukrainian regulations were a large corpus of documents based on the regulations of the USSR and which were written in a specific vocabulary, that even translated, still was difficult to understand for foreign architects.

${ }^{30}$ During our $\mathrm{PhD}$ study we assisted as the most part of the discussions between the foreign and Ukrainian participants at this project.

31 Author's interview with the Ukrainian Architect Director of Budova Centre-1. Additionally, during our discussion with other design firms in Ukraine in May 2010, the director of one of them recognized they refused the partnership with bdpgroupe6 because of the very main differences of the project and the existing hospitals in Ukraine and also, their building national regulations.
} 
symbolic ones (keep their initial design and avoid seeing a "soviet hospital" with their name on $\left.\mathrm{it}^{32}\right)$.

Also for economic reasons, the World Bank in Moldova opposed to modernizing primary Centers upon the national building regulations. But the context of this opposition was different of the Ukrainian case. In the Moldavian project there was initially no particular concern for the international standards of design or the international experience of foreign consultants, as only national design firms were appointed. In the same time, the new Health Centers that had to be redesigned upon new architectural layouts and new healthcare needs that the ministry considered following developments during the post-soviet decades. During the Soviet Union, the primary medical assistance was provided essentially in policlinics or rural Medical Points. Policlinics were larger and Medical Points smaller than the Health Centers the Ministry of Health wanted to build in 2007. In addition, during the soviet period, the characteristics of the healthcare facilities (medical points, policlinics or hospitals) were decided by the Ministry of Health of the USRR upon the principles of the soviet healthcare system Semashko ${ }^{33}$. This time, the central Moldavian authority could estimate the characteristics of the desired healthcare facility, depending on the number of population of the region, the medical staff and the healthcare services provided.

The characteristics of the re/construction of primary Centers in Moldova were agreed with the World Bank's representatives, according to the credit's conditions. Put simply, the international organization supervised the implementation of the credit. For this, the Ministry of Health had permanent discussions with the World Bank. The organization had local consultants within the ministry who worked with the civil servants on the project ${ }^{34}$. This way, the characteristics of each Health Center, their repartition on the territory as well as their number were agreed with the World Bank. As one of organization's consultants explained while informing about the usual procedure of contracts realized with the World Bank support:

"The World Bank has specialists in all the areas and especially in medicine. And the person who is specialized in medical insurance can look also on the contract mission and tell: "here you need to complete", "here you need to take out" etc. So, there are comments from the World Bank. Sometimes, if there are critical moments, even if they do not have a specialist on that question, they invite one ${ }^{, 35}$.

According to contractual mission of Health Centers' reconstruction, 65 Health Centers were supposed to be modernized within the Bank's credit. It is upon this mission that the Ministry

\footnotetext{
${ }^{32}$ Author's observation during discussions within bdpgroupe6 members.

${ }^{33}$ Semashko was the name of the First Health Commissioner of the USSR who gave the name to the soviet healthcare system. Its main principles were: Health is a State priority; Health must be free for everyone; the Health Policy should be centralized and unified in USSR; the priority of the Health system is the preventive medicine etc. For more details, see Leichter, Howard M., A Comparative Approach to Policy Analysis: Health Care Policy in Four Nations (Cambridge: Cambridge University Press, 1979), 326., p. 211.

${ }^{34}$ By "local consultant" of the World Bank we mean local specialists who were appointed by the organization to assist the Ministry of Health on the project involvement. As we saw during our internship at the Ministry, they were usually civil servants of the Ministry who for a year or two were paid by the World Bank to work on their projects and who could return therefore within the ministry.

35 Author's interview with World Bank consultant, Ministry of Health of Moldova, Chisinau, Moldova, March 2010 .
} 
of Health selected local architectural companies. Until this moment of the project, we can see that the World Bank did not intervene directly in the content of the contractual mission with the local companies. Although it discussed with the Ministry the characteristics of the future healthcare facilities, there were no objections and no demand of respecting some international standards. However, it should be noted here that the conditions of the new Health Centers elaborated by the Ministry of Health were different from the medical institutions of the Soviet Union. In particular, the size of it was reduced, as well as the services provided. As explains a member of the project within the Ministry, the Health Centers were in the past District hospital, with some more medical services than the rural Medical Points and considerably less than a regional hospital. Following the independence, some of these former hospitals were closed and some other were redesigned under the Health Centers project:

"I would say that this process evolved until 2001 when more than 250 district hospitals were closed. In fact, these institutions, with maximum from 50 to 100 beds, without surgical bloc, there were only some easy surgical operations, in fact, were not profitable at all. So the medical services provided, their cost was so low that it was impossible to maintain this hospital with an administration, with doctors, with nurses, with all that infrastructure inherited from the Soviet Union... "36.

The difference between the new dimensions of the Health Centers and those of the medical institutions of the soviet period was the starting point of debates between the local actors and the World Bank. Even if the contractual mission specified more reduced layouts, the Moldavian design firms point to the fact that the national building regulations did not allow them to design all the elements wanted by the Ministry of Health. In particular, some of the rules obliged them to respect the characteristics of a medical facility specific to the soviet period. In result, the Health Centers were much more expansive than the cost estimations made initially by the Ministry of Health and agreed with World Bank. It appeared that in order to respect Moldavian regulations, only 35 Health Centers could be modernized and not 65 as initially planned. In this context, the World Bank expressed its opposition: the organization did not want to reconstruct fewer Centers than it would have been possible with the credited resources.

If in Ukraine, foreign architects were attached to their design proposal, as well as to their financial fees in opposing to the respect of Ukrainian regulations, the World Bank opposed for economic reasons as well. In the same time, it was not about making profit, as in the case of private firms in Ukraine, but for not using irrationally the granted resources. Both Ukrainian and Moldavian cases also points to the fact that neither the Ministry of Health, not the World Bank, was initially aware of the problem of building regulations in Moldova. Similarly to the Ukrainian case, the problem of incompatibility between the new needs in healthcare sector and the building national regulations appeared following the evolutions within the first of the two sectors. But why were the national building regulations of these post-soviet countries a problem for modernizing the healthcare facilities?

\footnotetext{
${ }^{36}$ Author's interview with civil servant at the Ministry of Health of Moldova, Chisinau, Moldova, March 2010.
} 


\section{B) Are the Ukrainian and Moldavian building regulations a problem for introducing the foreign experience}

During the USSR, Ukraine and Moldova had much of the same public policies. These were political orientations developed by central organs of the Soviet Union and implemented through public policy instruments ${ }^{37}$. The design and building of healthcare facilities was at the center of the health policy and of the policy of construction. The soviet central ministries of Health and of Construction decided of the number of hospitals to be built on the territory of each republic, of the health services to be provided, on the characteristics of the healthcare facilities. For example, one political line was the large number of hospitals, which explains that both Ukraine and Moldova (as well as number of other former soviet countries) inherited of an exceeding number of hospital beds following their independence. If the health policy concerned the development of medical institutions and their function, the policy of construction structured the construction of medical buildings. All soviet republics shared common characteristics of construction buildings, starting with the building regulations of this activity and ending with the use of construction materials. A central organ of USSR - the Gosstroy $^{38}$ - elaborated the main policy orientations and the policy tools which were followed by each soviet republic. Among the various policy instruments, the building regulations were one of the largest in the area of the construction of healthcare facilities. During the Soviet Union, both Ukrainian and Moldavian national actors (authorities, architects and engineers) used the same soviet building regulations - called $\mathrm{SNIP}^{39}$ and $\mathrm{GOST}^{40}-$ for the construction and modernization of hospitals, policlinics, medical points etc.

If the collapse of the USSR meant the ending of the soviet political and economic system, this did not apply to all of its institutions. As Claus Offe and Jon Elster put it, there was no tabula rasa following the independence of the post-soviet countries and the change produced in these countries were rather progressive than immediate ${ }^{41}$. In the absence of new institutional arrangements, both Ukraine and Moldova saved the inherited ones. The case of the building regulations is an example of this king of institutional continuity. Given the fact that these technical norms regulate the activity of construction and that the national ministries did not elaborate new ones, both Ukraine and Moldova adopted following the independence the soviet building regulations as national ones. As the majority of architects and civil servants interviewed during our investigation confirmed, the soviet SNIP and GOST were re-adopted under different titles after 1991 (DBN for Ukraine and NCM for Moldova). Nevertheless, except their name, the content remains the same.

\footnotetext{
${ }^{37}$ We adopt the definition of Pierre Lascoumes and Patrick Le Galès of a public policy instrument: "a device that is both technical and social, that organizes specific social relations between the state and those it is addressed to, according to the representations and meanings it carries", in Lascoumes, Pierre et Patrick Le Galès, «Introduction: Understanding Public Policy through Its Instruments-From the Nature of Instruments to the Sociology of Public Policy Instrumentation», Governance 20, no. 1 (2007), 1-21., p.4.

${ }^{38}$ The Gosstroy was an executive organ (an Executive State Committee) in charge of elaborating the main policy lines of the building construction in USSR (and which were adopted by the national ministries of each republic).

${ }^{39}$ The soviet SNIP (in Russian "sanitarnyie normi i pravila") represent the building technical regulations of the USSR.

${ }^{40}$ The GOST (in Russian « gossudarstvenyie standarti ») represent the building technical standards of the USSR.

${ }^{41}$ Elster, Jon et al., Institutional Design in Post-Communist Societies: Rebuilding the Ship at Sea (Cambridge: Cambridge University Press, 1998).
} 
If the continuity of building regulations under the soviet form during the first decade could be linked to the lack of any national document, it is subject of more intense discussions twenty years after the Soviet collapse. Our research points to the absence of major reform in both post-soviet states concerning the building regulations ${ }^{42}$. The question of the transformation of the inherited technical norms is raised by the architects and engineers of these countries, who in order to introduce new equipments, technologies and building materials, point to the need of reforming the institutional framework. As they explain, the soviet building regulations were very detailed and stipulated precisely the size, the layout, the equipments and the materials that a healthcare facility should contain. Given the fact that many of these parameters evolved together with the evolution of the science and technology, the inherited norms need to be revised ${ }^{43}$. Thus, when the national actors of the health sector started the modernization of healthcare facilities, the national building regulations were an obstacle to this process, both in Ukraine and in Moldova ${ }^{44}$.

\section{III ) How did the international actors manage to implement their foreign experience of hospital design?}

How did the international actors modernize the healthcare facilities of Ukraine and Moldova if the national building regulations of these countries were an obstacle to it? As shows the case of the Children Hospital of the Future in Kiev and the re/construction of Health Centers in Moldova, foreign actors opposed to respecting the national regulations which intended to modify the architectural solutions they suggested. Even if quite different, both had economic reasons to insist on introducing the international experience. Our hypothesis was that given the difference of status and action capacity if these actors, they did not apply the same measures to convince the national actors of introducing the foreign experience. We supposed the World Bank had more power to impose its will than the private companies in Ukraine. Thus, the transfer of foreign design standards should be more direct and top-down than in the case of private firms.

\section{A) The negotiated transfer of private firms}

The detailed analysis of the case of Kiev hospital showed that foreign consortium bdpgroupe6 took a long time to negotiate with local actors the implementation of its model of hospital design. This point was crucial during the beginning of the project and especially for the contract signature, but also during the design works. The Foundation Ukraine 3000 signed the contract five months following the international competition. If bdpgroupe6 obtained not to entirely respect the national Ukrainian regulations, it still had to obtain the authorities certificates before receiving the payment of the mission. In the same time, the financial representatives of bdpgroupe 6 managed to negotiate the support of the Foundation for the

\footnotetext{
${ }^{42}$ Attempts to reform the inherited regulations were announced several times since 2000, both in Ukraine and in Moldova, but no transformation was performed until presently, in particularly concerning the design of healthcare facilities.

${ }^{43}$ Author's interviews with Ukrainian and Moldavian architects and engineers.

${ }^{44}$ We do not develop here the reasons of the continuity of building regulations in Ukraine and in Moldova twenty years following their independence, but notice that this is linked to the absence of clear political agenda as well as of the lack of national resources.
} 
introduction of foreign design solutions during the project. Following the initial conflict on the building regulations, the Foundation accepted to help the private firms in introducing their experience in Ukraine. In particularly, the organization addressed the problem of foreign design incompatibility with national regulations to the President Viktor Youshchenko, who called national ministries (of Health, of Construction, of Environment) to work on the implementation of the project. Additionally, the hospital project obtained the Experimental Status in Ukraine, which allowed deviating from national regulations, while producing a convincing justification. These national actions comforted the Foundation in supporting the introduction of foreign hospital design. It also stresses the fact that the only willingness of introducing the international experience without the political support of the President would have not suffice to pursue the project against the national regulations. The Foundation had intense debates with the foreign architects on the respect of Ukrainian building norms and signed the contract only when it obtained the presidential political support.

The Kiev project also points to the ability of international firms to negotiate for the adoption of their design solutions. Bdpgroupe6 had no means to make pressure on signing the contract with the Foundation. As we observed, the four months of signature expectation put the foreign firms under tension. They advanced resources for the international competition (the sketch design preparing) as well as for the initial stages following it (the starting of design plans, the visits of the site in Ukraine etc.). If the Foundation did not sign the contract, bdpgroupe6 would have lost the initial investments in the project, without any refund. So they insisted on keeping the original design and deviating from some Ukrainian regulations in discussions with the Foundation, but without disposing of coercive means. In this context, the strategy of the private practice was to convince the Foundation that she needs a modern advanced hospital and that Ukrainian regulations do not permit it; that only their international experience would provide a performing hospital on the image of those of Western countries; that they were aware of respecting the necessary regulations in Ukraine and of obtaining the authorities certificates, but in the same time, did not agree to transform their hospital design into a soviet one. The foreign private firms simply insisted on the "selling" of their "international hospital design" for which they were initially selected at the competition. They also took into account the fact that the Foundation had no interest to fail signing the contract, given the popularity and political image of this project in Ukraine.

\section{B) Coercion through World Bank technical assistance}

The World Bank in Moldova had different attitude in the Health Centers project. The international organization held a more strong discourse to the national actors than the foreign private firms in Ukraine did. In particular, the World Bank did not agree to pursue the project if its conditions were not to be respected. The Ministry of Health signed for a contractual mission of 65 Health Center modernizations and finally presented only 35 for effective realization, which could seem suspicious. Even if the national actors claimed that the number of modernization became lower according to the application of national building regulations, the international organization was attached to the rational management of granted resources. The World Bank insisted in recalculating the number of possible building modernization within the project. According to ministry's representatives, its opposition to changing the 
initial contractual mission was not to be discussed ${ }^{45}$. The international organization played thus the card of conditionality: the resources were credited under specific conditions, agreed by the both parts and the non-respect of these conditions could suspend the granted resources. As explained another project member, the World Bank granted a credit to the Government of Moldova and a problem with the Ministry of Health would had repercussion on the overall image of the country ${ }^{46}$.

In order to recalculate the number of Health Centers to be modernized, the World Bank appealed to foreign architects. The latter estimated the dimensions and characteristics of the Centers to be build, as well as their cost, within the sum of the project. As pointed the national building specialists themselves ${ }^{47}$, the Moldavian national regulations, mostly inherited of the soviet period, constrained the construction of Centers to larger dimensions that the new equipments and technologies henceforward allowed. There was a difference of building cost between the estimations of foreign consultants appointed by the World Bank and the estimations of Moldavian architecture companies appointed for the project. Given the fact that the cost evaluations of international consultants allowed for a larger number of Health Centers re/constructions, the World Bank required for the Ministry of Health to keep their suggestions.

At the difference of the Ukrainian case, in Moldova, the international organization did not put in place a negotiation strategy aiming to convince of the necessity to adopt the foreign experience. The Health Centers project shows that the World Bank has sufficient resources and pressure means to require the adoption of foreign solutions. Indeed, the Ministry of Health did not insisted on the necessity of respecting the national building regulations, as the Foundation Ukraine 3000 did. Instead, it adopted the design standards presented by the foreign architects appointed by the World Bank. Following this procedure, the Ministry of Health presented to the Ministry of Construction a demand of deviating from the national building regulations. At the difference of Ukraine, the Ministry did not wait for the approval or the support of national authorities or political representatives, before taking into account the foreign actor's demand. Consequently, the relation between the national and international actors was different in analyzed cases, concerning the introduction of foreign design experience. Although, in both countries, national actors of the health sectors modernize the healthcare facilities with the support of international actors, the nature (coercive or negotiated) of the transfer of foreign experience varies depending on the resources of the later: more the foreign actors dispose of pressure means on national actors, more they can impose the deviation of national inherited regulations ${ }^{48}$.

\footnotetext{
${ }^{45}$ Author's interview with a civil servant at the Ministry of Health of Moldova, in charge of the Health Centers project implementation, Chisinau, Moldova, April 2010.

${ }_{46}$ Author's interview with a civil servant at the Ministry of Health of Moldova, in charge of the Health Centers project implementation, Chisinau, Moldova, March 2010.

47 Author's interview with a civil servant at the Ministry of Health of Moldova, in charge of the Health Centers project implementation, Chisinau, Moldova, April 2010.

48 This does not suppose that the result of the transfer is more positive in the case of coercive means. As we saw in the project of Health Centers in Moldova, the World Bank certainly made the Ministry of Health adopt the international standards for the contractual mission. Nevertheless, the international organization did not
} 


\section{Conclusion}

This article questioned the role of international actors, such as private firms and international organizations, in transferring the foreign experience in post-soviet states. It took the case of a concrete public policy domain - the modernization of healthcare facilities - in order to present the national and foreign actors involved, the transfer strategies deployed as well as the obstacles and catalyst to this process. The aim of the article was to detail the role of non-state actors as "carriers" of foreign standards, thus enlarging the debates on soft-forms of transfer.

We initially argued that while both international organization and private firms introduce foreign standards of hospital design in Ukraine and Moldova, the mechanisms of transfer differ. Our hypothesis was that the World Bank in Moldavian project used of more coercive means to transfer foreign standards than the private firms in Ukraine. The detailed analysis of two modernization projects validates this hypothesis.

The results of our research investigation show that in Moldova, the World Bank disposed of pressure means, especially through the technical assistance provided to national actors, to require the adoption of international standards. The organization engaged its own consultants in order to check upon the efficiency of the standards to be adopted in the Health Centers project and insisted in taking into account the foreign ones, as they allowed a more efficient use of the credited resources. The World Bank played the card of the conditionality of the granted financial resources in order to obtain the adoption of foreign standards.

In Ukraine, the private firms we observed in the Kiev Children Hospital of the Future deployed a strategy of "selling" their international design. They tried to convince of the merits of the hospital design of Western countries and the necessity of deviating from the inherited building of the Soviet Union. In opposite to the international organization, the business firms did not possess coercive means to make the national actors accept the architectural solutions they proposed. Instead, they used of commercial strategies for convincing the national actors to adopt the foreign experience.

In conclusion, we remark that international transfers took place in post-soviet states in the context of an initial local demand of foreign experience. International organizations, private practices and other non-state actors use various mechanisms (coercion, learning) to transfer their experience, therefore participating at institutional national changes. The elements presented in this paper stress the fact that both Ukraine and Moldova wanted to modernize the healthcare facilities inherited of the soviet period on the model of the western countries developments. The international actors that they call in to this process strengthen the initial national actions, inciting the Ukrainian and Moldavian officials of the health sector to urge the reform of the unchanged national building regulations.

supervised the project during its implementation and some Moldavian construction firms still used the national regulations, thus spending more than initially scheduled. 


\section{Bibliography}

Atun, Rifat, et al. 2008. «Moldova: health system review.» Dans Health Systems in Transition, ed. The European Observatory on Health Systems and Policies: Euro WHO.

Brunsson, Nils, et al., dir. 2000. A world of standards. New York: Oxford University Press Inc.

Delpeuch, Thierry. 2008. «L'analyse des transferts internationaux de politiques publiques : un état de l'art.» Questions de recherche (27).

Dolowitz, David P. et David Marsh. 2000. «Learning from Abroad: The Role of Policy Transfer in Contemporary Policy-Making.» Governance 13 (1): 5-23.

Elster, Jon, et al. 1998. Institutional Design in Post-Communist Societies: Rebuilding the Ship at Sea. Cambridge: Cambridge University Press.

Füglister, Katharina. 2012. «Where does learning take place? The role of intergovernmental cooperation in policy diffusion.» European Journal of Political Research 51 (3): 31649.

General Accounting Office of the Republic of Moldova. 2011. «Audit Report of the project "Healthcare and Social Assistance Services" for the period 2007-2010/ Raportul auditului operațional al Proiectului „Servicii de Sănătate şi Asistenţă Socială” pentru perioada iunie 2007- 2010.». Chisinau, Moldova: Curtea de conturi a Republicii Moldova.

Lascoumes, Pierre et Patrick Le Galès. 2007. «Introduction: Understanding Public Policy through Its Instruments-From the Nature of Instruments to the Sociology of Public Policy Instrumentation.» Governance 20 (1): 1-21.

Leichter, Howard M. 1979. A Comparative Approach to Policy Analysis: Health Care Policy in Four Nations. Cambridge: Cambridge University Press.

Lekhan, Valeria, et al. 2004. Health care systems in transition: Ukraine. Copenhagen: WHO Regional Office for Europe on behalf of the European Observatory on Health Systems and Policies.

Lekhan, Valery, et al. 2010. «Ukraine: Health system review.», ed. European Observatory on Health Systems and Policies. Copenhagen: Euro WHO.

Ministry of Health of Republic of Moldova. 2008. «Report of activity of Miistry of Health for the year 2007/Raport de activitate a Ministerului Sanatatii pentru anul 2007.». Chisinau, Moldova.

Nay, Oliver. 2012. «How Do Policy Ideas Spread among International Administrations? Policy Entrepreneurs and Bureaucratic Influence in the UN Response to AIDS.» Journal of Public Policy 32 (1): 53-76.

Ministry of Health of Republic of Moldova. 2003. Order of the Ministry of Health regarding the institution of the health structure of region/municipality/ Ordin al Ministerului 
sanatatii cu privire la instituirea structurii sistemului sănătăţii raionale/municipale. 190.

Saurugger, Sabine et Yves Surel. 2006. «L'élargissement de l'Union européenne : un processus de transfert institutionnel ?»Introduction 13 (2): 177-8.

Simmons, Beth A., et al. 2008. The Global Diffusion of Markets and Democracy. New York: Cambridge University Press.

Stone, Diane. 2000. «Non-Governmental Policy Transfer: The Strategies of Independent Policy Institutes.» Governance 13 (1): 45-70.

- 2010. «Private philanthropy or policy transfer? The transnational norms of the Open Society Institute.» Policy \& Politics 38 (2): 269-87.

Turcanu, Ghenadie , et al. 2012. «Republic of Moldova: Health system review.», ed. the European Observatory on Health Systems and Policies. Copenhagen: Euro WHO. 